\title{
BOOK REVIEW: $A$ LONG TIME COMING: THE STORY OF NGÄI TAHU'S TREATY SETTLEMENT NEGOTIATIONS WITH THE CROWN
}

\author{
Carwyn Jones*
}

Martin Fisher A Long Time Coming: The story of Ngāi Tahu's Treaty Settlement Negotiations with the Crown (Canterbury University Press, 2020).

In A Long Time Coming, historian Martin Fisher provides an accessible and engaging account of Ngāi Tahu's journey towards the settlement of their historical claims. This is an important story to be told, and not just for those who whakapapa to Ngāi Tahu.

This book covers a lot of ground in a relatively short space. It begins with a history of the Ngāi Tahu claim itself. This provides important context for understanding the settlement negotiations that followed, but does so concisely - sensibly, there is no attempt to reproduce the full detail of the Waitangi Tribunal's three volume report. From there, the book charts the course of the negotiations toward a settlement. This includes initially setting a negotiating framework with the Crown, at a time in which the Crown was developing its general principles and policies for the settlement of historical claims. Whereas more recent settlement negotiations have taken place within a well-established framework, Ngāi Tahu (along with Waikato-Tainui, as the other early movers in this space) were working within a relatively uncertain policy context, with all parties aware that these first settlements would set a precedent for what was to follow. The journey of the settlement negotiations reminds us how dramatically the political environment has shifted in the intervening years. Today, the need to provide some redress for historical breaches of Te Tiriti o Waitangi is generally recognised across the political spectrum, but this could certainly not be taken for granted throughout the 1990s, when Ngāi Tahu were engaged in their negotiations. However, it is striking to note that the Crown's settlement

* Pūkenga Matua (Lead Academic), Ahunga Tikanga (Māori Laws and Philosophy), Te Wānanga o Raukawa; Honorary Adjunct Professor, Te Kawa a Māui (School of Māori Studies), Te Herenga Waka | Victoria University of Wellington. 
policy today continues to produce many of the same barriers and frustrations encountered by Ngāi Tahu in this process three decades earlier.

In some ways, this book might be seen as the official history of the negotiations. Fisher is a researcher at the Ngāi Tahu Research Centre at the University of Canterbury and the book has been researched and published with the support of the Centre. It includes a foreword from Tā Tipene O'Regan, former chairperson of the Ngāi Tahu Negotiating Group and of Ngāi Tahu Maori Trust Board. Fisher is interestingly positioned to write this account. He does not whakapapa to Ngāi Tahu, nor was he directly involved in Ngāi Tahu's settlement negotiations. But he has clearly been supported by Ngāi Tahu in this work, drawing on the iwi archives as one key aspect of the historical record, and supplementing documentary sources with interviews with key protagonists. This is, therefore, an account presented at arms-length, by an historian making sense of the narrative that emerges from the sources available. It is not a personal reflection from someone who was in the room as the decisions were being made and agreements struck. This has both advantages and disadvantages. The official record may not always reveal the nuance of discussions and motivations that direct participants might have observed or experienced. On the other hand, standing back from a distance to reflect on the full journey to settlement provides a perspective not available to those directly involved in the day-to-day progress of the negotiations. In any case, as Tā Tipene notes in the foreword, "[w]hilst some may quibble with the odd conclusion and the acuity of the occasional observation, this work will stand as the definitive account of a significant phase in this nation's historical journey".

I agree that this book is likely to be the definitive account of Ngāi Tahu's settlement negotiations, and that this does indeed represent a significant phase in the nation's historical journey, as the period when the framework for the programmatic, negotiated settlement of historical claims evolved. However, one criticism I have of the book is that, given the significance of the Ngāi Tahu negotiations in the development of the modern settlement process, it is surprising, and a little frustrating, that the book does not engage more in the broader settlement context. The book is squarely focused on telling the story of the Ngāi Tahu negotiations and the broader legal and political context is addressed only so far as it has an impact on the Ngāi Tahu story. Yet, there is much to be drawn from Ngāi Tahu's experience that could speak to the development of the settlement process and perhaps explain decisions of the Crown and other iwi in later settlements. Fisher is certainly well-placed to provide such analysis. Aside from his research on the Ngāi Tahu negotiations, Fisher has also worked at the Waitangi Tribunal and what was then known as the Office of Treaty Settlements (now, Te Arawhiti). Perhaps that might be the basis of a future project.

Although I would have liked to have seen the reach and ambition of the book extended, the focused account of the Ngāi Tahu settlement that Fisher has produced is, in itself, extremely valuable. As someone who has been involved in settlement negotiations as a negotiator for my own iwi, the overriding feeling I had while reading this book was that every settlement deserved this kind of treatment. That is, a readable and authoritative account from the settling group's perspective; an account that makes visible the work that a settling community needs to undertake; the challenges the 
community encounters; the principles which guide iwi negotiators; and the context for decisions that are made along the way. I would encourage anyone who is interested in the settlement process and the Māori-Crown relationship to read this book. And I would encourage other iwi to think about how to tell the important stories of their own settlements. 
(2021) 52 VUWLR 